\title{
Makna Teologis Kata Perhentian dalam Ibrani 4:1-14 (Analisis Tekstual, Stuktural, Kontekstual dan Intertekstual)
}

\author{
Daniel Lindung Adiatma ; Saul Arlos Gurich ${ }^{2}$ \\ Sekolah Tinggi Teologi Injili Indonesia Ambon ${ }^{1}$; STT Gereja Injili di Indonesia ${ }^{2}$ \\ Korepondensi: atmadaniel26@gmail.com ${ }^{1}$; saularlosgurich@gmail.com²
}

\begin{abstract}
Abstrak: Ada kecenderungan penafsir kitab Perjanjian Baru menafsirkan teks dengan pendekatan topikal. Pendekatan ini relevan bagi penelitian pada bidang teologi Kristen. Masalahnya, pendekatan topikal memiliki kecenderungan mengabaikan kesatuan unsur-unsur kitab. Oleh karena itu, diperlukan suatu model penafsiran topikal yang disempurnakan dengan kesatuan teologi kitab. Topik tentang makna teologi kata "perhentian" menarik perhatian para penafsir pada akhir-akhir ini. Topik tersebut merupakan bagian kecil yang membangun teologi kitab Ibrani secara keseluruhan. Artikel ini memaparkan tiga analisa (tekstual, kontekstual dan intertekstual) sebagai pendekatan untuk menemukan makna teologi kata "Perhentian" dalam kitab Ibrani 4:1-14. Penulis mempertimbangkan kitab Ibrani sebagai bentuk akhir untuk menemukan makna kata "perhentian" dalam konteks teologi kitab Ibrani. Penulis berusaha melakukan sinkronisasi tiga pendekatan tersebut dalam menemukan progresifitas makna kata "Perhentian" baik dalam kitab Perjanjian Lama maupun kitab Perjanjian Baru. Hasil penelitian melalui tiga pendekatan tersebut telah menampilkan adanya peningkatan makna kata "Perhentian" dari konteks Perjanjian Lama dan Perjanjian Baru. Akhirnya, artikel ini dapat mendukung teori pewahyuan progresif yang selama ini diyakini oleh kaum injili dispensasi.
\end{abstract}

Kata kunci: katapausin, Ibrani 4:1-4, tekstual, kontekstual, intertekstual

\begin{abstract}
There is a tendency for many commentator of the New Testament to interpret the text with a topical approach. This approach is relevant for research in the field of Christian theology. The problem is, the topical approach has a tendency to ignore the unity of the elements of the book. Therefore, we need a model of topical interpretation that is perfected with the unity of the theology of the book. The topic of the theological meaning of the word "rest" has attracted the attention of interpreters recently. These topics are the small sections that make up the theology of the book of Hebrews as a whole. This article presents three analyzes (textual, contextual and intertextual) as an approach to finding the theological meaning of the word "rest" in Hebrews 4:1-14. The author considers the book of Hebrews as the final form to find the meaning of the word "rest" in the theological context of the book of Hebrews. The author tries to synchronize the three approaches in finding the progressive meaning of the word "cessation" in both the Old Testament and the New Testament. The results of research through these three approaches have shown an increase in the meaning of the word "rest" from the context of the Old and New Testaments. Finally, this article can support the theory of progressive revelation that dispensational evangelicals have long believed.
\end{abstract}

Keywords: katapausin, Hebrew 4:1-4, textual, kontextual, intertextual 


\section{PENDAHULUAN}

Salah satu masalah yang ditimbulkan dalam suatu tafsiran adalah ketidaksesuaian antara penafsiran dengan konteks kitab secara utuh. Beberapa penafsir berupaya menafsirkan suatu teks tertentu dengan kerangka topikal yang telah menjadi prepsuposisi penulis. Misalnya, kata "perhentian" dalam kitab Ibrani 4:1-14 ditafsirkan sebagai kerajaan Milenium sebelum orang percaya masuk ke dalam kerajaan sorga. Masalahnya, kitab Ibrani secara keseluruhan tidak memberikan penanda khusus bahwa kata "perhentian" tersebut merupakan kerajaan Milenium. Selain itu, kata tersebut juga sering ditafsirkan sebagai intermediate state, yaitu tempat yang menjadi perhentian sementara sebelum orang percaya memasuki sorga yang kekal. Namun, tafsiran tersebut menuai masalah karena tidak memperhatikan prinsip pewahyuan bertingkat (progressive revelation). Oleh karena itu, penafsir perlu mempertimbangkan kembali penafsiran kata "perhentian" sesuai dengan konteks atau semesta pembicaraan dalam tersebut.

Tulisan ini membahas tentang pandangan kaum injili dispensasi progresif dalam menafsirkan suatu teks yang mengandung hubungan intertekstual. Topik yang dipilih oleh penulis adalah tentang penggunaan kata "perhentian" dalam konteks kitab Ibrani 4:1-14. Beberapa alasan penulis memilih teks kitab Ibrani adalah sebagai berikut: pertama, kitab Ibrani merupakan kitab yang unik dari kitabkitab Perjanjian Baru lainnya. Materi-materi yang dipakai oleh penulis Ibrani lebih banyak mengandung alusi dan kutipan dari kitab-kitab Perjanjian Lama. Dalam proses penafsiran kitab Ibrani lebih baik dibungkus dalam kerangka kristosentrik. ${ }^{1}$ Kedua, Ibrani 4:1-11 mengandung kutipan dari kitab-kitab Perjanjian Lama. Pada kasus-kasus teks yang memuat kutipan atau alusi dari Perjanjian Lama, ekseget perlu lebih serius dalam melakukan penelitian. Kegagalan dalam memahami nas yang mengandung hubungan

${ }^{1}$ A.T Hanson, "Hebrew," in It Is Writen Scripture Writing Scripture, ed. D A. Carson (Cambridge: Cambridge University Press, 1988), 297. intertekstual dapat menyebabkan seseorang salah dalam menafsirkan suatu kebenaran alkitab. ${ }^{2}$

Tidak banyak penafsir yang memperhatikan proses penafsiran teks intertekstual dalam menafsirkan Ibrani 4:1-14. Misalnya, James A. Fowler yang dalam tafsirannya menekankan pada nilai-nilai kristosentrik. ${ }^{3}$ Selanjutnya, Ray C. Stedman menfasirkan kata "perhentian" bukan dalam arti tempat, melainkan secara fungsional. ${ }^{4}$

Tulisan ini akan memberikan suatu pandangan yang dapat menjadi alternatif dalam menentukan makna kata "perhentian" dalam surat kitab Ibrani 4:1-14. Penulis menggunakan metode tafsir tekstual, kontekstual dan intertekstual untuk mengemukakan makna kata "perhentian" dalam kitab Ibrani 4:1-4.

Artikel ini menekankan pada penggalian makna teologis suatu kata. Adapun perbedaan tulisan ini dengan studi kata pada umumnya adalah terletak pada proses penggalian makna. Dalam studi kata, biasanya penafsir hanya akan melihat perkembangan pemakaian makna kata dari bahasa Yunani kuno dan Yunani Koine. ${ }^{5}$ Pada artikel ini, penulis akan memperhatikan konteks sastra dan garis besar kitab untuk menemukan makna kata perhentian dalam konteks bentuk akhir kitab Ibrani.

Penulis menetapkan rumusan masalah dalam penelitian ini berupa pertanyaan riset yaitu, apakah makna teologi kata perhentian dalam kitab Ibrani 4:1-4? Rumusan masalah tersebut dikembangkan dalam bentuk roadmap penelitian sebagai berikut; Pertama, penetapan metode

${ }^{2}$ Daniel L. Adiatma, "Teknik Tafsir Pemakaian Perjanjian Lama Dalam Perjanjian Baru," Academia.edu, no. (2019), https://d1wqtxts1xzle7.cloudfront.net/59268 297/Teknik_Tafsir_Kutipan_PL_dalam_PB_Teknik_Tafsi r_Pemakaian_Habakuk_2_4_dalam_Roma_1_172019051 5-120083-o9o3x7.pdf?1557982815=\&response-contentdisposition=inline\%3B+filename\%3DTeknik_Tafsir_Kuti pan_PL_dalam_PB_.

James A. Fowler, A Commentary on the Epistle to The Hebrew (Fallbrook: C.I.Y Publishing, 2006), 140

${ }^{4}$ Ray C. Stedman, "Hebrews," in The New Testamnet Commentary Series, ed. Grant R Osborne (Downers Grove: InterVarsity, 1992), 37.

${ }^{5}$ Pendekatan tersbut lazim dipakai bagi pembelajar ilmu tafsir pada tingkat dasar. Biasanya para pembelajar mula-mula akan memanfaatkan buku karya dari Gerhard Kittel dan Geoffrey Bromiley yang berjudul Theological Dictionary of New Testament. 
penelitian. Kedua, implementasi metode penelitian terhadap teks yang telah ditetapkan. Ketiga, perumusan hasil penelitian berdasarkan proses penelitian yang tlah dilaksanakan.

Adapun tujuan penelitian ini adalah untuk menemukan makna teologi kata "perhentian" dengan memperhatikan bentuk akhir kitab (final form). Penulis meeyakini bahwa kitab Ibrani harus dipahami sebagai karya sastra teologis. Artinya, penafsir tidak dapat memahami suatu bagian dari kitab tersebut tanpa memahami keseluruhan isi kitab. Oleh karena itu, tujuan utama dari penelitian ini adalah untuk menggiring para pembaca memahami makna kata "perhentian" dalam terang kitab Ibrani secara keseluruhan.

\section{METODE}

Jenis penelitian yang dilakukan penulis merupakan penelitian kualitatif berupa penelitian historis dengan meneliti dokumendokumen keagamaan. Oleh karena itu sumber utama (primary sources) penelitian ini adalah Alkitab Perjanjian Baru versi Nestle-Aland, Novum Testamentum Graece 28th edisi revisi, disunting oleh Barbara dan Kurt Aland, Johannes Karavidopoulos, Carlo M. Martini, dan Bruce M, Metzger bekerjasama dengan Institute for New Testament Textual Research, Münster/ Westphalia, 2012 Deutsche Bibelgesellschaft, Stuttgart. Dalam karya tersebut, biasanya selalu memberikan catatan kaki pada teks tersebut. Catatan kaki tersebut dapat dipakai sebagai rujukan unutk menemukan bagian kitab Perjanjian Lama yang telah dikutip.

Lebih dari 1400 tahun, kitab Perjanjian Baru disalin menggunakan tangan. Setiap salinan memungkinkan terjadinya kesalahan atau perbedaan antara masing-masing salinan. Ada sekitar 5,338 manuskrip berbahasa Yunani dan lebih dari 8000 salinan berbahasa latin. ${ }^{6}$ Keadaan tersebut menuntut kerja keras ekseget untuk memilah-milah teks yang relevan sebagai

${ }^{6}$ Eldon Jay. Eep and D. Fee, Gordon, Studies In The Theory and Method of New Testament Textual Critisism (Grand Rapids: William B. Eerdmans Publishing Company, 2000). 3. sumber utama (primary sources) dalam proses eksegesa.

Selanjutnya, sebagai sumber kedua (secondary sources), penulis akan memanfatkan beberapa buku alat untuk menggali informasi seputar teks. Penulis memanfaatkan kamus, leksikon dan beberapa catatan dari proses penyalinan manuskrip. Informasi tersebut penting untuk mengetahui berbagai kemungkinan penafsiran. Penulis juga memanfaatkan sumber pelangkap (complementary sources) yang akan dipakai oleh penulis berupa buku tafsir, penelitian para ahli, monograf dsb yang akan berinteraksi dengan hasil tafsiran dari penulis. Dengan demikian hasil tafsiran akan semakin dipertajam. Beberapa prosedur tafsir yang akan dilakukan penulis dipaparkan di bawah ini.

Pertama, melakukan investigasi terhadap konteks kitab Perjanjian Baru yang menggunakan Perjanjian Lama. Ekseget harus dapat membedakan apakah teks tersebut merupakan kutipan atau alusi. Ibrani 4:1-11 memuat pemakaian Perjanjian Lama dalam Perjanjian Baru dari berbagai kitab Perjanjian Lama. Beberapa kitab Perjanjian Lama yang dikutip oleh penulis Ibrani 4:1-11 dibungkus dalam suatu tema yaitu tempat perhentian. Pada tabel berikut ini mencatatkan hubungan intertekstual bagian nas kitab Ibrani dengan kitab-kitab Perjanjian Lama.

\begin{tabular}{|l|l|}
\hline \multicolumn{1}{|c|}{ Nas Ibrani } & \multicolumn{1}{c|}{ Kutipan PL } \\
\hline Ibrani 4:3 & Mazmur 95:11 \\
\hline Ibrani 4:4 & Kejadian 2:2 \\
\hline Ibrani 4:5 & Mazmur 95:11 \\
\hline Ibrani 4:7 & Mazmur 95:7-8 \\
\hline Ibrani 4:8 & Ulangan 31:7; Yos. 22:4 \\
\hline Ibrani 4:10 & Kejadian 2:2 \\
\hline
\end{tabular}

Berdasarkan penelaahan tekstual, jelas bahwa bentuk pemakaian Perjanjian Lama dalam Ibrani 4:1-11 adalah berupa kutipan langsung. Pentingnya nas-nas Perjanjian Lama dikutip dalam kitab Ibrani 4:1-11 adalah sebagai contoh negatif orang-orang Israel dalam menanggapi firman Allah. Ibrani 4:1-2 merupakan transisi oleh penulis Ibrani dalam menjelaskan topik ketidakpercayaan dan ketidaktaatan (Ibrani 3:7- 
19) kepada penjelasan mengenai janji Allah kepada orang percaya. ${ }^{7}$

Selain itu, juga dilakukan pendataan teks salinan (kritik teks). Kritik teks merupakan bagian dari kritik rendah (lower criticism) yang berbeda dengan kritik tinggi (higher criticism) yang berisi kritik historis dan kritik literal. Kaum injili memegang konsep kritik rendah dengan melakukan penelitian pada salinan-salinan naskah Perjanjian Baru. Kritik tinggi biasa dipakai oleh kaum liberal guna menemukan historitas penulisan.

Tujuan kritik teks adalah untuk membuktikan autensitas sebuah tulisan dan penulis. Pertanyaan yang perlu diajukan dalam proses eksegesis adalah apa yang dikatakan oleh teks? Apa arti sesungguhnya dari teks tersebut? Seorang ekseget harus memahami teks asli secara akurat untuk memahami sebuah nas. Pemahaman terhadap berbagai varian teks menolong penafsir memahami pemahaman sejarah mula-mula terhadap suatu teks. ${ }^{8}$

Kedua, investigasi konteks Perjanjian Lama yang telah dikutip. Penelaahan konteks memegang peranan penting dalam proses eksegesis intertekstual. Ekseget harus menganalisis konteks Perjanjian Lama secara luas maupun langsung, khususnya menafsirkan secara menyeluruh paragraf tempat kutipan tersebut muncul. Kepentingan dari tahap ini adalah memberikan wawasan dalam kutipan Perjanjian Lama yang tidak terlihat sebelumnya. Dalam bagian ini penafsir harus melakukan penafsiran nas Perjanjian Lama yang dikutip melalui eksegesis sesuai dengan konteks Perjanjian Lama tanpa dipengaruhi Perjanjian Baru. ${ }^{9}$ Jadi, terkait dengan Ibrani 4:1-11, ekseget

${ }^{7}$ George H. Guthrie, "Hebrew," in Commentary On The New Testament Using Old Testament, ed. Gregory K. Beale and D A. Carson (Grand Rapids: Baker Academic, 2007). 1740.

${ }^{8}$ Eep and Fee, Gordon, Studies In The Theory and Method of New Testament Textual Critisism. 3.

${ }^{9}$ Tahap ini dilakukan dengan tiga tahap. Pertama, menganalisis konteks luas Perjanjian Lama tempat Perjanjian Baru merujuk nas tersebut. Kedua, masuk dalam konteks kitab terkutip dan fokus pada eksegesis kitab tersebut. Ketiga, menghubungkan kutipan Perjanjian Lama dengan apa yang muncul lebih dahulu dan lebih akhir dalam kitab kanonis. Lihat Gregory K. perlu melihat konteks kitab Kejadian 2:2, Ulangan 31:7, Yosua 22:4 dan Mazmur 95.

Ketiga, membuat tabulasi teks Perjanjian Lama dan Perjanjian Baru untuk menemukan perbedaan. Bagian ini memerlukan pengamatan yang lebih serius, karena berdasarkan tabulasi ini ekseget dapat memutuskan apakah penulis Perjanjian Baru mengutip langsung dari Masoretik Teks (MT) atau Septuaginta (LXX). Memang jarang sekali ditemukan kutipan langsung dari MT karena Septuaginta telah dianggap sebagai kitab orang Yahudi bagi mereka yang tidak memahami tulisan Ibrani. Dalam dunia Perjanjian Baru, Septuaginta lebih dominan dipakai sebagai sumber ajaran daripada Masoretik Teks (MT), khususnya bagi orangorang Kristen-Yahudi di perantauan.

Keempat, menganalisa sumber kutipan yang dipakai oleh penulis Perjanjian Baru. Analisa ini adalah untuk mengetahui naskah apakah yang telah dikutip. Bagi penulis Perjanjian Baru yang mengutip langsung dari MT, biasanya menggunakan beberapa metode antara lain, menerjemahkan langsung teks, menafsirkan ulang teks atau mengutip sebagian dan menambahkan ide baru.

Pada bagian ini ekseget menganalisis penggunaan Perjanjian Lama secara tekstual oleh penulis Perjanjian Baru. Penafsir harus memperhatikan perubahan-perubahan dasar antara teks Ibrani, Septuaginta, dan Perjanjian Baru. ${ }^{10}$ Dengan memperhatikan perubahanperubahan tersebut, maka penafsir dapat memastikan apakah penulis Perjanjian Baru mengutip secara langsung atau atau melakukan reinterpretasi terhadap nas Perjanjian Lama.

Pada saat menganalisa kitab Perjanjian Lama yang telah dikutip, ekseget juga harus memperhatikan jenis literatur (genre) kitab. Tahap selanjutnya adalah menafsirkan kitabkitab Perjanjian Lama sesuai dengan jenis literatur untuk memperoleh maksud asli penulis dalam kitab tersebut. Setelah penulis melakukan eksegesis terhadap kitab yang telah dikutip,

Beale, Penggunaan Perjanjian Lama Oleh Perjanjian Baru (Malang: SAAT, 2015).

${ }^{10}$ Ibid. 
ekseget juga harus melakukan eksegesis nas sesuai dengan konteks Perjanjian Baru.

Kelima, mencari hubungan teologis kedua kitab. Hubungan teologis akan ditemukan setelah melakukan tahapan eksegesis dari masing-masing kitab. Salah satu gaya penulisan yang dipakai oleh penulis Perjanjian Baru dalam memakai Perjanjian Lama adalah dengan mengambil topik-topik tertentu. Misalnya kitab Ibrani 4:1-11 mengutip dari empat kitab yang berbeda, namun semua kitab yang telah dikutip terikat pada tema "perhentian."

\section{PEMBAHASAN}

Bagian ini merupakan rumusan hasil dari serangkaian proses penafsiran yang telah ditetapkan oleh penulis sebelumnya. Penulis memaparkan pembahasan dengan tiga sub sub bab, yaitu analisa tekstual, analisa kontekstual dan analisa intertekstual. Masing-masing bagian akan memaparkan hasil penelaahan yang sinkronik di antara ketiga analisa tersebut.

\section{Analisis Tekstual}

Bagian ini mencatakan hasil investigasi terhadap teks Ibrani 4:1-14. Penulis akan memaparkan terjemahan langsung dari bahasa Yunani kepada bahasa Indonesia dan memberikan beberapa catatan terjemahan. Pentingnya analisa tekstual adalah untuk memberikan data yang valid sebagai kajian dalam penafsiran.

\section{Analisa Terjemahan dan Unsur Gramatika}

Berikut ini adalah terjemahan teks Yunani ke dalam bahasa Indonesia dan penjelasan unsur-unsur gramatika yang terkandung dalam teks Yunani.

\begin{tabular}{|c|c|}
\hline Bahasa Yunani & Terjemahan \\
\hline 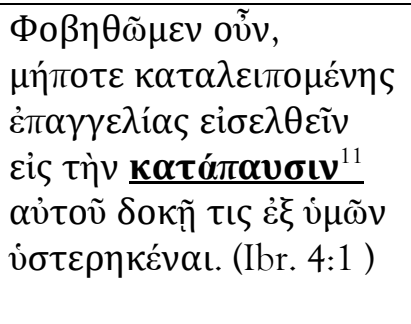 & $\begin{array}{l}\text { Karena itu kita harus } \\
\text { waspada, sementara } \\
\text { janji masuk ke tempat } \\
\text { perhentian-Nya masih } \\
\text { terbuka, kiranya tidak } \\
\text { ada seorangpun } \\
\text { tersesat. }\end{array}$ \\
\hline 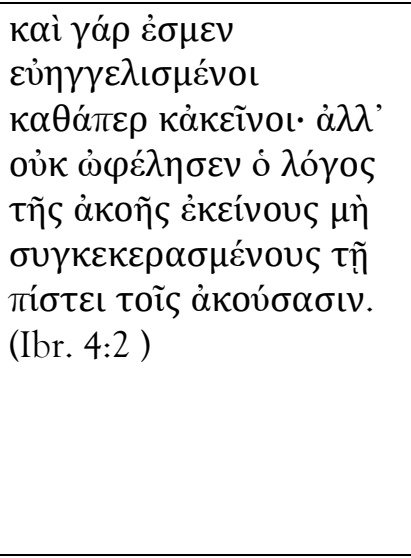 & $\begin{array}{l}\text { Karena kita telah } \\
\text { memiliki kabar baik } \\
\text { (injil) yang diberitakan } \\
\text { kepada kita, seperti } \\
\text { kepada mereka. Tetapi } \\
\text { firman yang mereka } \\
\text { peroleh tidak berman- } \\
\text { faat bagi mereka karena } \\
\text { yang mereka telah } \\
\text { dengar tidak bekerja- } \\
\text { sama dengan kesetiaan } \\
\text { mereka. }\end{array}$ \\
\hline 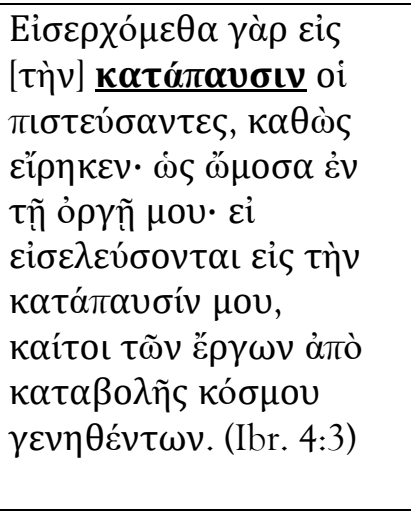 & $\begin{array}{l}\text { Karena orang percaya } \\
\text { akan masuk ke dalam } \\
\text { perhentian sebagaimana } \\
\text { Dia berkata "Aku ber- } \\
\text { sumpah dalam murka- } \\
\text { Ku, mereka tidak akan } \\
\text { masuk ke dalam tempat } \\
\text { perhentian-Ku." } \\
\text { Meskipun pekerjaan- } \\
\text { Nya telah selesai pada } \\
\text { saat penciptaan. }\end{array}$ \\
\hline 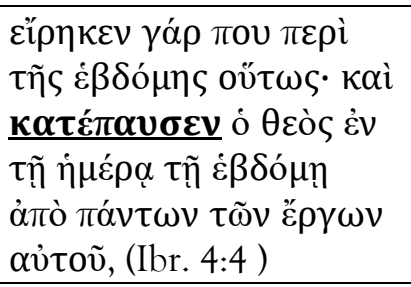 & $\begin{array}{l}\text { Karena di suatu bagian } \\
\text { (kitab) berbicara } \\
\text { tentang hari ketujuh } \\
\text { "dan Allah berhenti } \\
\text { pada hari ketujuh dari } \\
\text { semua pekerjaanNya." }\end{array}$ \\
\hline 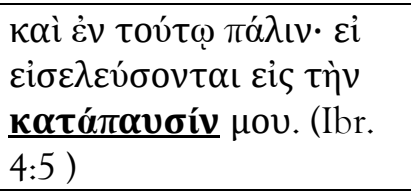 & $\begin{array}{l}\text { Dan tentang itu lagi } \\
\text { "mereka tidak akan } \\
\text { pernah masuk dalam } \\
\text { tempat perhentian-Ku." }\end{array}$ \\
\hline 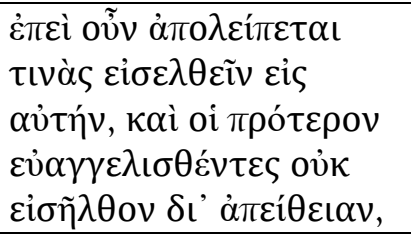 & $\begin{array}{l}\text { Karena itu, ada } \\
\text { beberapa orang akan } \\
\text { masuk ke tempat itu, } \\
\text { sedangkan mereka } \\
\text { yang kepadanya lebih }\end{array}$ \\
\hline
\end{tabular}

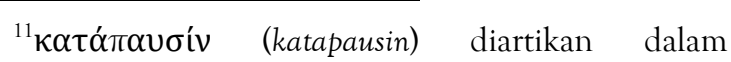
beberapa maksud. Pertama, suatu kadaan seseorang yang sedang beristirahat. Kedua, diartikan sebagai lokasi atau tempat peristirahatan. Ketiga, berhubungan dengan spiritual dan keadaan sorgawi. Barbara Friberg, Timothy Friberg, and Neva F. Miller, Analytical Lexicon of The New Testament (Grand Rapids: Baker Books, 2000). 


\begin{tabular}{|c|c|}
\hline (Ibr. 4:6 ) & $\begin{array}{l}\text { dahulu diberitakan } \\
\text { kabar baik itu, tidak } \\
\text { masuk karena } \\
\text { ketidaktaatan mereka. }\end{array}$ \\
\hline 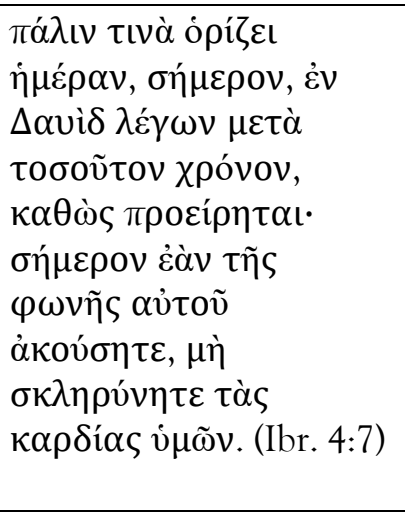 & $\begin{array}{l}\text { Allah menetapkan suatu } \\
\text { hari yang disebut "hari } \\
\text { ini" ketika dia } \\
\text { berfirman melalui } \\
\text { Daud, setelah sekian } \\
\text { lama, seperti yang } \\
\text { dikutip pada bagian ini } \\
\text { "O, hari ini engkau } \\
\text { mendengar yang Dia } \\
\text { katakan, janganlah } \\
\text { keras-kan hatimu". }\end{array}$ \\
\hline 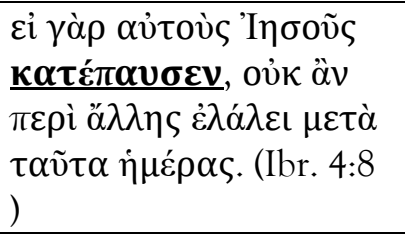 & $\begin{array}{l}\text { Jika Yosua telah } \\
\text { memberi mereka } \\
\text { istirahat } \\
\text { tidak akan berbicara } \\
\text { tentang hari yang lain. }\end{array}$ \\
\hline 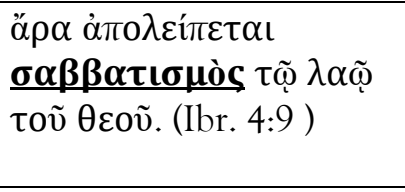 & $\begin{array}{l}\text { Sehingga masih } \\
\text { tersedia suatu hari } \\
\text { istirahat, hari ketujuh, } \\
\text { bagi umat Allah. }\end{array}$ \\
\hline 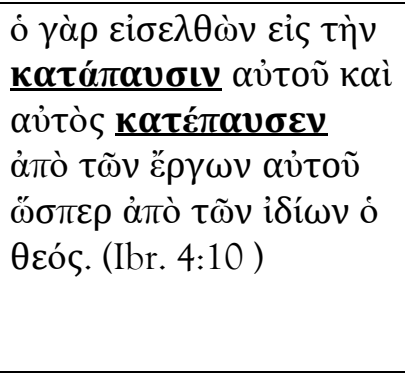 & $\begin{array}{l}\text { Karena barangsiapa } \\
\text { yang masuk dalam } \\
\text { perhentian Allah juga } \\
\text { beristirahat dari } \\
\text { pekerjaannya } \\
\text { sebagaimana Allah } \\
\text { berhenti dari semua } \\
\text { pekerjaanNya. }\end{array}$ \\
\hline 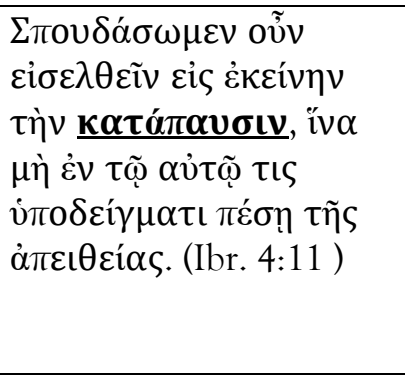 & $\begin{array}{l}\text { Karena itu marilah kita } \\
\text { memakai setiap usaha } \\
\text { untuk masuk ke dalam } \\
\text { peristirahatan, } \\
\text { sehingga tidak ada } \\
\text { seorangpun yang jatuh } \\
\text { sama seperti contoh } \\
\text { ketidaktaatan. }\end{array}$ \\
\hline
\end{tabular}

Struktur kalimat dalam kitab Ibrani 4:1-11 tidak mudah dipahami. Oleh karena itu beberapa terjemahan menambahkan tafsiran kedalam terjemahannya. Misalkan, dalam Ibrani

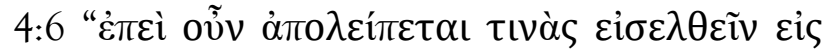

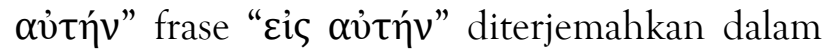

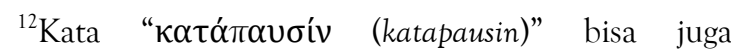
diartikan beristirahat. Pemakaian tergantung pada konteks kalimat atau perikop. Wilbur F. Gingrich, Shorter Lexicon of the Greek New Testament, ed. Frederick W Danker, 2nd ed. (Chicago: The University of Chicago Press, 2007). 103.
}

Terjemahan Baru "masuk ke tempat perhentian itu”. Penulis merasa hal tersebut merupakan hasil dari penyunting Terjemahan Baru. Jika

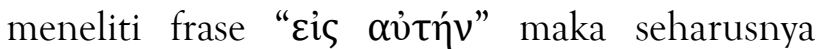
diterjemahkan "dalam-nya." Gender kata zis

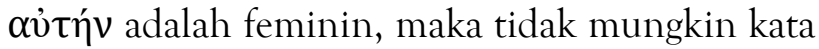
ini mewakili Allah ( $\theta \varepsilon$ cò, Theos) yang bergenre maskulin. Berdasarkan pertimbangan konteks kalimat beberapa terjemahan seperti New International Version dan Terjemahan Baru menerjemahkan perhentian. Namun, tidak demikian dengan beberapa terjemahan seperti New American Standart (NAS) dan New English Translation (NET). Jadi perlu penelitian serius dan penguasaan dialektik-dialektik Greco-Roman dalam menganalisis teks ini.

Kata "berhenti, beristirahat" dalam nas

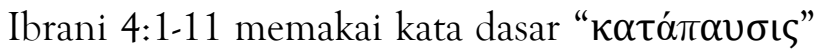
(katapausis) sebanyak 8 kali dengan berbagai macam penggunaan dan kata " $\sigma \alpha \beta \beta \alpha \tau \iota \sigma \mu o ̀ \varsigma "$ (sabatismos) sebanyak 1 kali. Materi Ibrani 4:1-11 berisi narasi-narasi Perjanjian Lama. Pemakaian Israel, Yosua dan Daud menunjukkan bahwa sebagian besar isi dari nas ini merupakan contohcontoh yang dipakai penulis dalam menjelaskan peneguhan bahwa Allah memberikan tempat istirahat. Pemakaian kata-kata yang merupakan terminologi Perjanjian Lama seperti

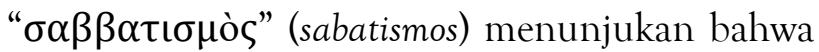
penulis sedang menunjukan adanya relasi antara konteks tersebut dengan kitab-kitab Perjanjian Lama.

\section{Analisa Kritik Teks}

Beberapa catatan penyalinan perlu dianalisa secara mendalam dengan pendekatan kritik teks. Dalam kitab Ibrani 4:1-14 terdapat beberapa permasalahan tekstual yang perlu diteliti secara mendalam. Berikut ini adalah hasil pengkajian yang dilakukan oleh peneliti terkait dengan catatan penyalinan teks.

Ibrani 4:1-10 memuat beberapa perbedaan dalam beberapa salinan. Penulis berusaha menggali informasi seputar perbendaan salinan tersebut. Pada bagian ini penulis akan mengkaji data-data yang telah dicatatkan dalam alkitab versi UBS (United Bible Society $4^{\text {th }}$ ) yang lain 
dikenal dengan The Greek New Testament (GNT). Alkitab versi ini memiliki bentuk teks sama persis dengan Perjanjian Baru Yunani NestleAlland edisi 26 dan 27.

Salinan $\mathrm{P}^{46}$ memuat tulisan Paulus (Roma-II Tesalonika) dan Ibrani. Cukup mengherankan bahwa salinan tahun 200 memasukkan kitab Ibrani pada tulisan-tulisan Paulus (Paulin Epistle). Namun susunan kata dalam kalimat, paragraf dan perikop sama sekali berbeda dengan pola penulisan surat-surat Paulus. Penulis tidak sedang bermaksud menggiring pada opini bahwa kemungkinan Paulus adalah penulis kitab ini, tetapi penulis hanya sekadar menampilkan fakta bahwa dalam salinan tertua, kitab Ibrani ditemukan bersama-sama dengan tulisan-tulisan Paulus.

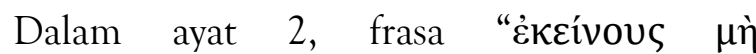

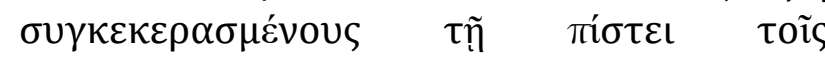

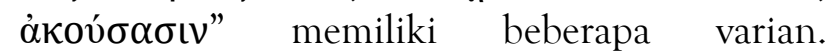
Berdasarkan pengamatan dari peneliti, varian yang dipercaya dan mendekati dengan teks asli adalah varian Papirus $13\left(\mathrm{P}^{13}\right)$ dan Papirus 42 $\left(\mathrm{P}^{42}\right)$. Teks $\sigma u \gamma \kappa \varepsilon \kappa \varepsilon \rho \alpha \sigma \mu \varepsilon ́ v o u \varsigma$ merupakan teks yang mendekati aslinya mengingat bahwa tekst tersebut disalin pada papyrus Abad ke II dan Abad Ke III.

Kitab versi UBS4 dan NA26 memakai kata

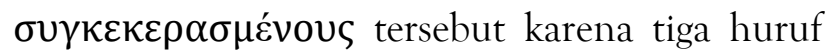
terakhir (ous) disinyalir luntur. Berdasarkan penelitian mendalam pada $\mathrm{P}^{13}$ menyatakan bahwa tiga huruf terakhir adalah "ous."

Secara gramatika kata $\sigma u \gamma \kappa \varepsilon \kappa \varepsilon \rho \alpha \sigma \mu \varepsilon ́ v o u \varsigma$ dinilai lebih masuk akal karena didahului dengan kata દ̇kcívous yang merupakan lawan

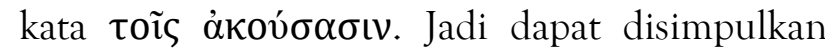
kata yang mendekati teks asli adalah

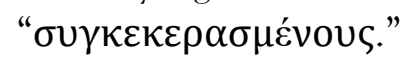

Selanjutnya dalam ayat 3 terdapat kata

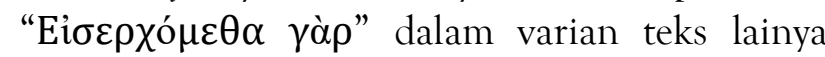
tertulis "Ei̋ $\sigma \rho \chi 0 ́ \mu \varepsilon \theta \alpha$ oun." Teks yang

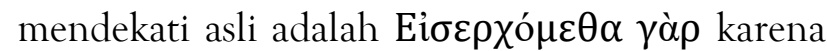
disalin pada $\mathrm{P}^{13}, \mathrm{P}^{42}$. Berdasarkan susunan

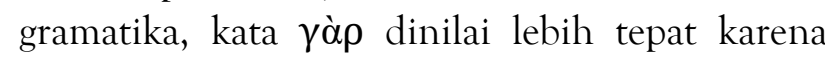
menghubungkan dengan kalimat sebelumnya (struktur tersebut akan terlihat jelas pada diagram).

Dalam ayat yang sama terdapat perbedaan

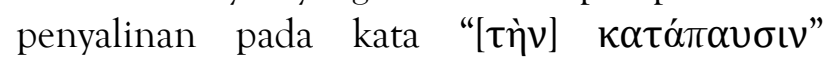

sedangkan beberapa varian tidak menyertakan

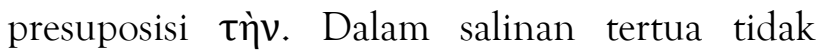

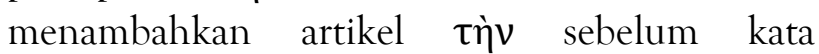

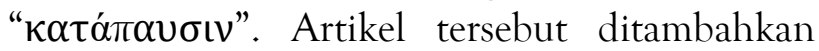
pada salinan-salinan yang lebih muda, misalnya kodek Sinaitikus (\$) sekitar tahun 350 untuk menjelaskan "tempat persitirahatan tertentu" yang diikuti dengan kutipan dari Perjanjian

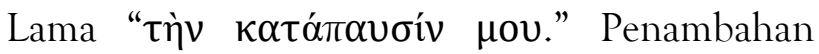
tersebut untuk menegaskan suatu keadaan spiritual yang beristirahat penuh.

Dalam Ibrani 4:3c dan 4:5 konjungsi عỉ (jika) memuat masalah dalam papyrus $13\left(\mathrm{P}^{13}\right)$. Dalam Papirus tersebut tidak ditambahkan konjungsi tersebut. Berdasarkan edition precept of $\mathbf{P}^{13}$ yang ditulis oleh P.Oxy, 657, kata tersebut seharusnya

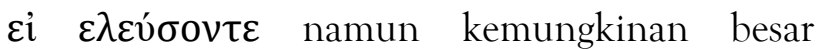
terbaca $\varepsilon i ̉(\sigma) \varepsilon \lambda \varepsilon v ́ \sigma o v \tau \alpha$ เ."13 Perbedaan tersebut menunjukan bahwa pembaca jangan memahami kalimat tersebut sebagai kalimat pengandaian (conditional statement) "jika mereka masuk pada perhentianKu," melainkan sebagai kalimat larangan "mereka tidak akan masuk pada perhentian-Ku).

Dalam Ibrani 4:6 dan 4:11. Menurut kebanyakan manuskrip dalam Ibrani 4:6 dikatakan bahwa "bangsa Israel tidak masuk ke tanah Kanaan karena ketidaktaatannya

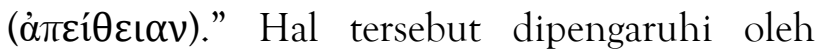
Ibrani 3:19 yang telah diubah menjadi "tidak percaya $(\dot{\alpha} \pi \iota \sigma \tau i ́ \alpha \nu)$ " seperti yang telah terdapat dalam salinan $\mathrm{P}^{46}$ dan $\mathrm{N}$. Perubahan tersebut juga terlihat dalam Ibrani 4:11 juga memakai kata

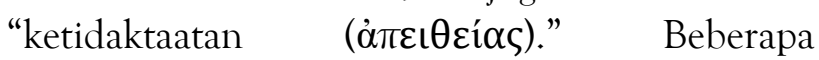
terjemahan Latin mempertahankan terjemahan dari $\mathrm{P}^{46}$ untuk menegaskan bahwa Israel tidak masuk ke tanah Kanaan bukan karena ketidaktaatan semata, namun dari semula mereka tidak percaya. Ketidakpercayaan tersebut menjadikan Israel tidak taat

\section{Analisa Struktural}

Langkah pertama dalam meneliti sebuah kitab adalah menentukan genre kitab tersebut. Genre utama kitab Ibrani adalah Epistolari. Hal

${ }^{13}$ Text Earliest MSS (Manuscript), 86 and Critical Apparatus of $\mathrm{NA}^{27}$ 
tersebut namapak dari struktur kitab secara keseluruhan yang ditandai dengan pengantar surat (Ibrani 1:1-4), isi surat (Ibrani 1:5 - 13:17) dan salam penutup (Ibrani 13:18-25). Namun dalam penyajian surat ini memakai nuansa khotbah (homily).

Salah satu langkah yang perlu dilakukan dalam menganalisa konteks adalah dengan melihat garis besar kitab secara keseluruhan. Garis besar kitab akan menolong penafsir memahami posisi nas tersebut dalam sebuah kitab. Garis besar kitab Ibrani diperlukan agar penafsir dapat memahami pentingnya nas Ibrani 4:1-11 dalam keseluruhan kitab Ibrani. Struktur kitab Ibrani secara keseluruhan adalah sebagai berikut.

I. Landasan Teologis Keunggulan Kristus (1:1-10:18).

A. Kristus Lebih Unggul daripada Para Nabi $(1: 1-4)$.

1. Penyataan Allah melalui para nabi $(1: 1)$.

2. Pernyataan Allah melalui Putera-Nya $(1: 2-4)$.

B. Kristus lebih unggul daripada para Malaikat (1:5-2:18).

1. Dinyatakan dalam Perjanjian Lama (1:5-14).

Peringatan Pertama: Jangan luput $(2: 1-4)$

2. Dinyatakan Melalui Kemanusiaan-Nya (2:5-18).

a. Positif: Dimuliakan di atas para Malaikat (2:5-9).

b. Negatif: Menderita untuk Dimuliakan (2:10-18).

1) Mengidentifikasi kemanusiaan (2:10-13).

2) Menghancurkan Iblis dan menyelamatkan orang-orang kudus (2:14-16).

3) Menjadi Imam yang berbelaskasihan dan penuh kesetiaan (2:17-18).

C. Kristus Lebih Unggul daripasa Musa (3:1-4:13).

1. Keduanya adalah setia (3:1-2).

2. Ahli Bangungan dan Bangunan (3:3-4)

3. Hamba dan Anak (3:5-6a).
Peringatan Kedua: Jangan Cacat (3:6b-4:13).

a. Israel di padang gurun (3:6b-11).

b. Peringatan terhadap ketidakpercayaan $(3: 12-4: 2)$.

c. Peringatan terhadap kegagalan masuk tempat Peristirahatan (4:3-13).

1) Pentingnya Iman (4:3-11).

2) Pentingnya Firman Allah (4:12-13).

D. Kristus Lebih Unggul Daripada Harun (4:14-7:28).

1. Kepedulian Imam Agung (4:14-16).

2. Keimaman Harun (5:1-5)

3. Keimaman Kristus (5:6-10).

Peringatan Ketiga: Jangan Mengalami Kemerosotan Iman (5:11-6:8).

a. Pengungkapan ketidakdewasaan (5:11-14).

b. Dorongan menjadi dewasa (6:1-3).

c. Peringatan terhadap kemurtadan (6:4-8).

4. Peringatan terhadap Janji Allah (6:9-20).

5. Keimaman Melkisedek (7:1-28).

a. Kebesaran Melkisedek dalam hubungannya dengan Abraham $(7: 1-10)$.

b. Kebesaran Melkisedek dalam hubungannya dengan keimaman (7:11-28).

E. Pelayanan Kristus Lebih Unggul daripada Pelayanan Perjanjian Lama $(8: 1-10: 18)$.

1. Pengantar (8:1-6).

2. Perjanjian yang lebih baik (8:7-13).

a. Ketidaksesuaian dengan penjanjian yang lama (8:7-9).

b. kesesuaaian perjanjian yang baru (8:10-13).

3. Tempat yang lebih baik $(9: 1-12)$.

a. Ketidaksempurnaan tempat di Bumi $(9: 1-10)$.

b. Kesempurnaan tempat di sorga (9:11-12).

4. Pengorbanan yang lebih baik (9:13-10:18).

a. Pentingnya darah yang tercurah (9:13-22). 
b. Pemurnian (9:23-28).

c. Pengorbanan yang permanen

(10:1-18).

1) Ketidaksesuaian sistem korban dalam keimaman (10:1-9).

2) Kesempurnaan Pengorbanan Kristus (10:10-18).

II. Praktek hidup atas keunggungulan Kristus (10:19-13:17).

A. Nasihat untuk memasuki tempat suci yang baru (10:19-31).

1. Beriman (10:19-22).

2. Berharap (10:23).

3. Saling Mengasihi (10:24-25).

Peringatan Keempat: Jangan memandang rendah (10:26-31).

B. Nasihat Agar Tetap Kuat Menghadapi

Penganiayaan (10:32-39).

C. Teladan Iman (11:1-40).

1. Pengantar (11:1-3).

2. Iman dari masa Habel sampai Nuh (11:4-7).

3. Iman Bapa-Bapa Beriman (11:8-22).

4. Iman Musa (11:23-29).

5. Iman Israel setelah era Musa (11:30-40).

D. Nasihat Agar Tetap Kuat menghadapi hajaran Allah (12:1-29).

1. Teladan Kristus (12:1-4).

2. Dihajar Allah bukti sebagai anak (12:5-11).

3. Dihajar Allah merupakan bagian untuk menyucikan (12:12-17).

Peringatan Kelima: Jangan Menolak (12:18-29).

a. Gunung Sinai dan Gunung Sion (12:18-24).

b. Betapa Mengagumkan Kekudusan Allah di Sorga (12:25-29).

E. Nasihat dalam Kehidupan Kristen (13:1-17).

1. Mengasihi saudara seiman (13:1-6).

2. Menghormati Pemimpin (13:7-17)

a. Meneladani Iman (13:7-8).

b. Menolak Ajaran Sesat (13:9-15).

c. Memelihara Pemimpin (13:16).

d. Mentaati Pemimpin (13:17).

III. Kesimpulan dan Himbauan (13:18-25).

A. Permohonan dalam doa (13:18-19).

B. Doa bagi para pembaca (13:20-21).
C. Nasihat terakhir (13:22).

E. Salam dan Doa (13:24-25)..

\section{Analisa Kontekstual}

Kitab Ibrani dibagi menjadi dua bagian utama. Pertama, landasan teologis keunggulan Kristus (Ibrani 1:1-10:18). Kedua, praktek hidup atas keunggulan Kristus (10:19-13:17). Dalam konteks kitab Ibrani secara keseluruhan, Ibrani 4:1-11 merupakan bagian dari landasan teologis keutamaan Kristus daripada Musa (Ibrani 3:14:13). Oleh karena itu pencarian makna terkait

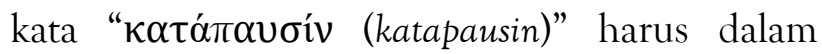
kerangka keunggulan Kristus. Artinya dalam proses penggalian makna kata tersebut, penulis akan mempertahankan frame kerangka konteks yang mengikat kata tersebut. Terkait dengan kata tersebut, penulis akan memaparkan dua sudut pandang penggalian kontekstual. Pertama, sudut pandang konteks kitab. Kedua, sudut pandang peningkatan pikiran penulis.

Konteks terdekat kata "perhentian" dalam struktur kitab Ibrani adalah sebagai berikut:

Kristus Lebih Unggul daripasa Musa (3:1-4:13)

1. Keduanya adalah setia $(3: 1-2)$

2. Ahli Bangungan dan Bangunan (3:3-4)

3. Hamba dan Anak (3:5-6a)

Peringatan Kedua: Jangan Cacat (3:6b-4:13)

a. Israel di padang gurun (3:6b-11)

b. Peringatan terhadap ketidakpercayaan

$(3: 12-4: 2)$

c. Peringatan terhadap kegagalan masuk tempat

Peristirahatan (4:3-13)

1. Pentingnya Iman (4:3-11)

2. Pentingnya Firman Allah (4:12-13)

Struktur khotbah adalah Landasan Teologis (Ibr. 3:1-6a), Peringatan (Ibr. 3:6b - 4:13). Peringatan tersebut berisi peringatan kegagalan masuk dalam tempat perhentian yang dijelaskan melalui kisah Israel dan pentingnya iman sebagai dasar untuk masuk dalam tempat perhentian. Fokus pada konteks ini adalah dua figur yang diperbandingkan.

Kristus lebih tinggi dari Musa (3:1 - 4:13). Penulis kitab berusaha menjembatani figur Kristus sebagai Imam yang penuh belas kasihan 
(2:17-18) melalui perbandingan Kristus dengan Musa. Pola yang dibuat penulis kitab adalah sebagai berikut.

Keunggulan Kristus

Atas para Malaikat $\rightarrow$ Musa $\rightarrow$ Harun $\rightarrow$ Melkisedek.

Penulis kitab Ibrani tidak melupakan keberadaan Musa dalam menjelaskan superioritas Kristus. Keberadaan Musa memiliki keterkaitan dengan perhentian Israel yang disebut Kanaan. Materi dalam Ibrani 3:7-19 berisi tentang sejarah ketidakpercayaan Israel. Ketidakpercayaan Israel menjadikan mereka tidak dapat memasuki tempat peristirahatan yang mereka tuju yaitu Kanaan.

Penulis mengajak agar pembaca mengarahkan pikirannya kepada Yesus sebagai Imam Besar (Ibr. 3:2). Penulis kitab menjelaskan Musa merupakan bangunan yang dibangun oleh Yesus (Ibr. 3:3). Keberadaan Musa adalah bangunan rumah dan Yesus adalah Anak yang mengepalai rumah tersebut. Mereka yang mempercayai Musa haruslah menaruh kepercayaan dan pengharapan kepada Anak sebagai kepala rumah yang telah dibangun. Jadi dalam bagian ini penulis kitab hendak menyadarkan kepada orang Yahudi Kristen agar menaruh kepercayaan dan pengharapan kepada Yesus (Ibr. 3:6).

Ibrani 3:12 merupakan peringatan bagi mereka yang tidak percaya dan murtad. B $\lambda \varepsilon ́ \pi \varepsilon \tau \varepsilon$,

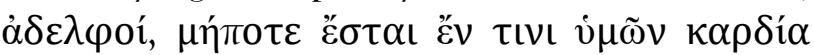

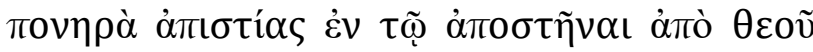

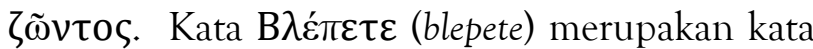
yang memiliki modus imperatif yang diikuti dengan kata kerja utama Ě $\sigma \tau \alpha \iota$ (estai) dengan kala future dan diatesis medial.

Kombinasi imperatival future sering terjadi pada literatur Perjanjian Baru yang mengutip kebenaran dari Perjanjian Lama khususnya kitab Pentateukh. ${ }^{14}$ Natur dari kalimat tersebut harus dipahami sebagaimana natur dalam Perjanjian Lama. Dengan demikian perintah agar tidak murtad merupakan hasil dari penulis kitab menyatir kebenaran Perjanjian Lama.

${ }^{14}$ Daniel B. Wallace, Greek Grammar Beyond the Basis: An Exegetical Syntax of the New Testament (Grand Rapids: Zondervan Publishing House, 1996). 596.
Selanjutnya pemakaian kala futur dalam Ibrani 3:12 tidak sedang membuktikan bahwa telah ada jemaat yang murtad. Pemakaian kala ini juga bukan merupakan nubuatan atau prediksi adanya kemurtadan. Dalam kasus ini penulis Ibrani hanya menjelaskan bahwa ada

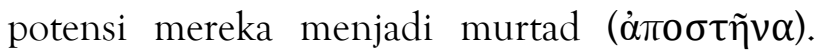
Namun kepastian terhadap kemurtadan tidak dijelaskan oleh penulis. Ibrani 3:16-19 menjelaskan ketidakpercayaan orang-orang Israel menjadikan mereka mati di padang gurun. Penekanan teks ini bukanlah pada tujuan tempat perhentian, melainkan ketidakpercayaan sebagian umat Israel sehingga Allah menghukum mereka tidak dapat sampai di tempat perhentian yaitu Kanaan. Fokus pada bagian nas Ibrani 3:719 adalah peringatan agar orang-orang percaya tetap dalam iman dan kepercayaannnya agar peristiwa Israel tidak menimpa mereka. Jadi tujuan penulisan nas ini adalah untuk membesarkan hati orang percaya agar berpegang teguh pada iman dan kepercayaannya.

Selanjutnya, penulis beralih pada topik "tempat perhentian Allah" berdasarkan beberapa

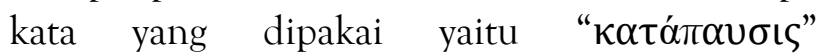

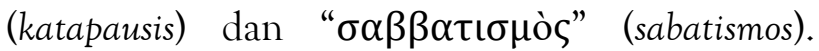
Artinya nuansa yang dibangun oleh penulis

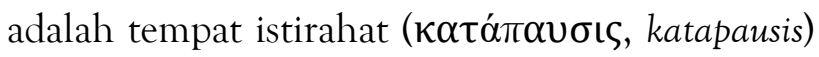
dan suasana berhenti dari pekerjaan orang-orang kudus " $\sigma \alpha \beta \beta \alpha \tau \imath \sigma \mu o ̀ \varsigma "$ (sabatismos).

Lalu, apakah hubungan antara tempat perhentian dengan keunggulan Kristus? Sebuah teks tidak pernah terlepas konteks yang mengelilingi teks tersebut. Sebelumnya dijelaskan bahwa Kristus lebih unggul daripada Musa. Bagan dibawah ini akan memberikan pencerahan terhadap pertanyaan diatas:

\begin{tabular}{|c|c|}
\hline Musa & Kristus \\
\hline $\begin{array}{l}\text { Musa merupakan } \\
\text { bangunan (Ibr. 3:2-3). } \\
\text { Musa dibangun untuk } \\
\text { hormat dan kemuliaan } \\
\text { ahli bangunan. }\end{array}$ & 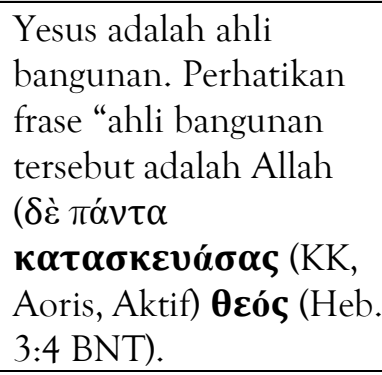 \\
\hline $\begin{array}{l}\text { Musa membimbing } \\
\text { orang Israel menuju ke }\end{array}$ & $\begin{array}{l}\text { Yesus memberikan } \\
\text { jaminan tempat }\end{array}$ \\
\hline
\end{tabular}


HUPËRETĒS: Jurnal Teologi dan Pendidikan Kristen 2 no. 2 (2021)

\begin{tabular}{|l|l|}
\hline $\begin{array}{l}\text { tempat perhentian } \\
\text { Allah (Kanaan) namun } \\
\text { beberapa orang gagal } \\
\text { masuk karena } \\
\text { ketidakpercayaan. }\end{array}$ & perhentian (Ibr 3:6) \\
\hline $\begin{array}{l}\text { Orang Israel yang } \\
\text { dipimpin Musa gagal } \\
\text { masuk ke dalam tanah } \\
\text { perhentian, kecuali } \\
\text { Yosua dan Kaleb. }\end{array}$ & $\begin{array}{l}\text { Orang-orang percaya } \\
\text { akan memasuki tempat } \\
\text { perhentian melalui } \\
\text { Kristus. Nuansa tempat } \\
\text { perhentian tersebut } \\
\text { adalah. } \\
\text { 1. Tempat beristirahat. } \\
\text { 2. Orang percaya } \\
\text { berhenti bekerja atau } \\
\text { selesai berjuang. } \\
\text { 3. Orang percaya } \\
\text { bersekutu bersama- } \\
\text { sama dengan Allah. }\end{array}$ \\
\hline
\end{tabular}

Jadi dalam sudut pandang konteks, disimpulkan bahwa tempat perhentian mengandung tiga pengertian. Pertama, tempat yang telah dijanjikan oleh Allah kepada orang percaya jauh lebih indah daripada tempat perhentian Israel (tanah Kanaan). Kedua, sebuah tempat dimana orang percaya akan berhenti dari pekerjaannya. Memang tidak dijelaskan maksud dari berhenti bekerja, namun pengertian ketiga akan meperjelas makna berhenti berkerja. Ketiga, berdasarkan pemakaian kata $\sigma \alpha \beta \beta \alpha \tau \iota \sigma \mu o ̀ s$ (sabatismos) menjelaskan bahwa di tempat perhentian tersebut orang-orang percaya akan bersekutu bersama-sama Tuhan.

\section{Analisis Intertekstual}

Bagian ini merupakan penerapan dari metode yang telah disusun oleh penulis pada bagian awal. Ayat tersebut dapat mewakili perikop Ibrani 4:1-10 terkait penelusuran makna nas tersebut. Berikut beberapa perbandingan teks yang telah dikutip:

\begin{tabular}{|c|c|c|}
\hline MTT & LXT & TEKS PB \\
\hline 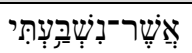 & $\dot{\omega} \varsigma \omega ̈ \mu \circ \sigma \alpha \dot{\varepsilon} v \tau \tilde{\eta}$ & 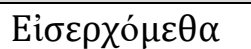 \\
\hline בְאַפְּיָּ & 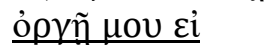 & 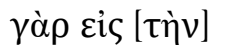 \\
\hline אִם-איאבאָאוּן & 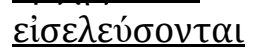 & 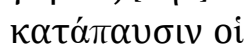 \\
\hline אֶל-מְְנוּחָתָי & Eis Tìv & $\pi / \sigma \tau \varepsilon v ́ \sigma \alpha \nu \tau \varepsilon \varsigma$, \\
\hline (Ps. 95:11 & 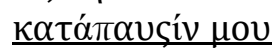 & $\kappa \alpha \theta \grave{\varsigma}$ \\
\hline WTT) & (Ps. 94:11 LXT) & 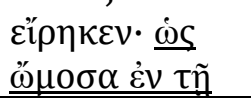 \\
\hline
\end{tabular}

\begin{tabular}{|c|c|c|}
\hline & & 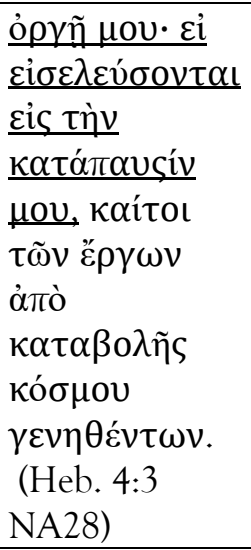 \\
\hline $\begin{array}{l}\text { Karena itu } \\
\text { aku } \\
\text { bersumpah } \\
\text { dalam } \\
\text { murkaku } \\
\text { mereka } \\
\text { tidak akan } \\
\text { masuk ke } \\
\text { dalam } \\
\text { perhentian- } \\
\text { Ku }\end{array}$ & $\begin{array}{l}\text { Sehingga aku } \\
\text { telah bersumpah } \\
\text { di dalam murka- } \\
\text { Ku, jika mereka } \\
\text { tidak akan masuk } \\
\text { pada ke dalam } \\
\text { perhentian-Ku }\end{array}$ & $\begin{array}{l}\text { Karena orang } \\
\text { percaya akan } \\
\text { masuk ke } \\
\text { dalam } \\
\text { perhentian } \\
\text { sebagaimana } \\
\text { Dia berkata } \\
\text { "Aku } \\
\text { bersumpah } \\
\text { dalam murka- } \\
\text { Ku, mereka } \\
\text { tidak akan } \\
\text { masuk ke } \\
\text { dalam tempat } \\
\text { perhentian- } \\
\text { Ku". Meskipun } \\
\text { pekerjaan-Nya } \\
\text { telah selesai } \\
\text { pada saat } \\
\text { penciptaan. }\end{array}$ \\
\hline
\end{tabular}

Berdasarkan tabulasi diatas dapat dilihat bahwa penulis Ibrani mengutip langsung dari LXX. Konstruksi kalimat dalam Ibrani 4:3 identik dengan LXX. Salah satu bukti bahwa penulis Ibrani mengutip mengutip langsung dari

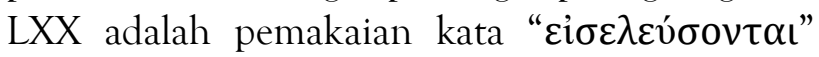
(eiseleusontai) yang merupakan kata kerja, futur, medial. Kata kerja medial mengandung makna refleksif, yaitu subjek juga menuai akibat dari tindakan tersebut.

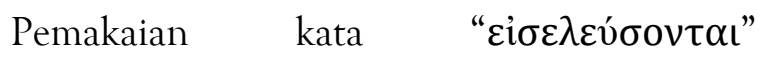

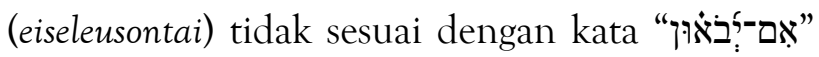
(im gebo'un) yang merupakan kata dengan stem Qal, Imperfek. Jika pemazmur hendak menekankan pada bentuk refleksif, maka seharusnya pemazmur akan memakai kata dengan stem hitpael atau salah satu dari fungsi dari stem nifal. Apakah ada perbedaan persepsi 
antara penulis Mazmur 95:11 dengan penerjemah septuaginta?

\section{Penelusuran Konteks Mazmur 95:11}

Konteks Mazmur 95:1-11 adalah ketaatan kepada TUHAN. Penulis membagi Mazmur 95 menjadi tiga bagian utama. Bagian pertama adalah Mazmur 95:1-5 berisi doxology. Bagian kedua adalah Mazmur 95:6-7a yang berisi ajakan menyembah TUHAN. Bagian ketiga adalah Mazmur 95:7b-11 yang berisi penerapan atau praktek hidup beriman kepada Allah yang diagungkan (ayat 1-5) dan Allah yang disembah (ayat 6-7b).

Ungkapan "jika hari ini kamu mendengar suara-Nya janganlah mengeraskan hatimu" merupakan kalimat ajakan halus dari pemazmur agar jemaah percaya sepenuhnya kepada firman Allah. Kata "קוֹ" (qol) dalam beberapa kitab Pejanjian Lama diartikan sebagai suara TUHAN atau Firman TUHAN. ${ }^{15}$ Biasanya Mazmur dinyanyikan dalam peribadatan Yahudi. Penekanan pemazmur adalah agar orang Israel mendengar firman dan menerimanya dengan hati yang terbuka.

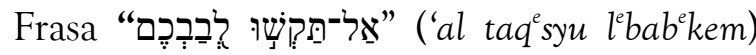
dapat diartikan "tidak menerima" firman atau perkataan TUHAN. LXX mempertegas terjemahan frase tersebut dengan memakai kata

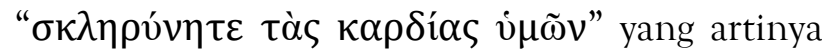
"janganlah hatimu menolak". Frase tersebut menjelaskan bahwa Israel keras kepala terhadap rencana TUHAN bagi mereka. Mereka tidak mempercayai TUHAN yang membimbing mereka keluar dari tanah Mesir menuju tanah perjanjian.

Bentuk ketidakpercayaan Israel adalah dengan terus menerus mencobai TUHAN.

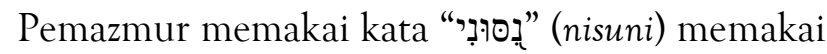
stem piel yang maknanya terus menerus atau intensif. Selanjutnya pemazmur menegaskan ketidakpercayaan Israel dengan frasa meskipun telah melihat pekerjaan-Ku patsali). Israel telah menjadi saksi mata

${ }^{15}$ William L. Holladay, A Concise Hebrew and Aramaic Lexicon of the Old Testament (Leiden: Koninklijke Brill NV, 2000). 315. perbuatan-perbuatan TUHAN selama dalam perjalanan menuju tanah perjanjian, namun reksi mereka tetap terus-menerus meragukan perbuatan-perbuatan TUHAN.

Penulis dengan sangat cerdas menjelaskan bahwa pemberontakan Israel tersebut adalah terus-menerus (intensif) melalui hadirnya stem

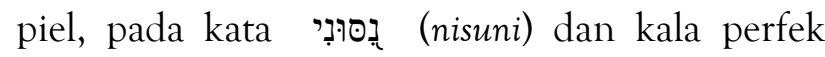

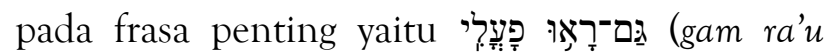
patsali). Kedua frase tersebut mendasari ayat 10 yang menyatakan bahwa:

\begin{tabular}{|c|c|}
\hline 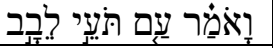 & Bangsa yang sesat hati \\
\hline 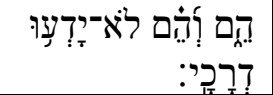 & $\begin{array}{l}\text { Bangsa yang tidak } \\
\text { mengetahui jalan-Ku }\end{array}$ \\
\hline
\end{tabular}

Dua frase penting memberikan keterangan bahwa Israel gagal memasuki tanah perjanjian sebagai tempat perhentian yang disediakan TUHAN bagi mereka. Ungkapan bangsa yang sesat hati, menegaskan kebodohan Israel yang tidak memahami bahwa TUHAN melakukan mujizat-mujizat bagi Israel untuk memelihara Israel. $^{16}$

Dalam literatur puisi kata "לרבָּ" (lebab) dimaknai juga dengan pikiran. Hal ini tidak lepas dari konsep dikotomi Yahudi terkait dengan unsur-unsur manusia. Khususnya dalam literature hikmat, seringkali penulis Amsal memakai kata "hati" untuk menegaskan pikiran. Salah satu sasaran pembelajaran Yahudi adalah pencerahan pikiran, menggerakkan emosi dan mencapai perubahan tindakan yang baik.

Israel telah melihat mujizat-mujizat TUHAN dalam perjalanan keluar dari Mesir dengan panca indera mereka. Sebenarnya ada dua hal penting yang meneguhkan Israel untuk dapat mencapai tanah perhentian yang telah disediakan Allah. Pertama, TUHAN berjanji kepada Abraham bahwa keturunan Israel akan memiliki tanah Kanaan. TUHAN mengikat perjanjian dengan Abraham yang disebut dengan perjanjian territorial atau perjanjian tanah (Kej.

${ }^{16}$ Ibid., 393. Kata "תiș" diikuti dengan kata benda "לברבי]" dapat diartikan sesat pikir atau bingung. Kata ini dalam Kel. 23:4 dipakai untuk menjelaskan binatang yang sesat. Barangkali penulis hendak mengingatkan bahwa Israel bodoh seperti binatang karena tidak mempercayai TUHAN. 
13:15-16). Kedua, TUHAN menunjukan pernyertaan-Nya melalui tiang awan dan tiang api (Kel. 13:21-22). TUHAN sendiri yang memimpin Israel keluar menuju tanah perjanjian. TUHAN juga menunjukan tanda penyertaan-Nya agar Israel tidak khawatir.

Ketidakpercayaan Israel menyangkali kedua peneguhan tersebut. Israel telah menyangkali perjanjian Allah kepada Abraham dan menyangkali kehadiran Allah sebagai pemimpin Israel melalui ketidakpercayaan. Hal itulah yang dijelaskan oleh pemazmur bahwa Israel sesat hati atau bodoh.

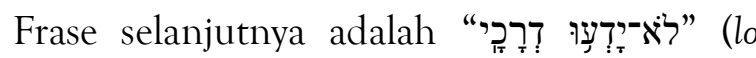
yad'tsu d'raka) yang diartikan tidak mengetahui jalanKu). Dalam struktur Mazmur 95:10, frase ini merupakan akibat dari frase sebelumnya. Artinya Israel tidak mengetahui jalan-jalan yang telah ditunjukan Allah karena kebodohan mereka yang tidak mau mempercayai TUHAN sepenuhnya. Atas dasar ketidak percayaan tersebut TUHAN bersumpah bahwa bangsa Israel generasi pertama tidak akan masuk ke tempat perhentian yang telah disediakan TUHAN.

Kata perhentian dalam MT memakai kata

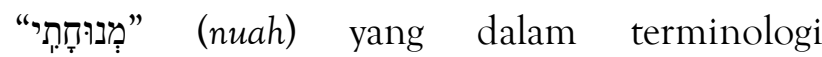
Yudaisme menunjukan suatu tempat yang disediakan agar seseorang mendapatkan peristirahatan yang baik, menyenangkan dan mulia. Menarik untuk diselidiki bahwa pemazmur tidak menyebutkan langsung tempat yang dimaksud adalah Kanaan, melainkan menyebutnya dengan tempat perhentian.

Dalam kasus tersebut penulis merasa bahwa pemazmur hendak menunjukan cakupan yang lebih luas dalam penggunaan kata perhentian. Penggunaan secara teologis kata nuah memiliki makna tempat beristirahat dari semua musuh. Penekanan dalam pemakaian ini adalah kedamaian yang sejati. Kanaan bukanlah tempat kedamaian yang sejati, karena disekitarnya banyak bangsa-bangsa yang siap menyerang Israel.

Ketika jemaah membaca Mazmur 95:11, tentu saja mereka akan menafsirkan bahwa tempat perhentian tersebut adalah Kanaan. Namun makna abadi yang dapat diperoleh dari Mazmur 95:1-11 adalah TUHAN yang besar layak disembah memberikan melalui iman dan kesetiaan memberikan kedamaian yang sejati. Jadi topik yang dikembangkan oleh penulis Ibrani 4:1-11 adalah kegagalan Israel beriman kepada TUHAN (Mzm. 95:7b-11).

\section{Penelusuran Konteks Ibrani 4:1-11}

Penulis Ibrani mengembangkan topik tentang iman dalam kaitannya dengan perjanjian tempat perhentian berdasarkan kitab Perjanjian Lama. Yosua 1:3 menegaskan bahwa tempat perhentian tersbut akan diterima melalui iman. Dalam kitab Ibrani, gereja memperoleh "perjanjian baru" berupa tempat perhentian. Tempat perhentian dalam perjanjian lama berlaku bagi mereka yang beriman penuh, menaruh pengharapan dan setia kepada Tuhan Yesus Kristus. Mereka beriman bahwa Yesus adalah Tuhan. ${ }^{17}$

Apakah orang Kristen akan masuk ke tanah Kanaan? Tentu saja tidak, karena perjanjian tanah (perjanjian teritorial) terbatas pada keturunan Abraham. Dengan demikian tempat perhentian yang dimaksud adalah tempat perhentian yang disediakan Tuhan bagi orang percaya. Penafsir harus berhati-hati dalam menafsirkan "tempat perhentian" karena ada kemungkinan penafsir akan terjebak pada penafsiran alegoris.

Gambaran mengenai tempat perhentian harus dipahami sebagai gambaran proses keselamatan. Proses tersebut ditandai dengan prosesi masuk kepada hadirat Allah di sorga (Ibr. 11:16) dan Kerajaan yang tidak tergoyahkan (Ibr. 12:28), dimulai dengan baptisan (Ibr. 12:28) dan disempurnakan secara keseluruhan dalam peristiwa eskatologis. ${ }^{18}$

Harus dipahami bahwa "tempat perhentian" dalam konteks Ibrani 4:1-10 merupakan

\footnotetext{
${ }^{17}$ Collin Brown, New Testament Theology, III. (Grand Rapids: Regency Library, 1993). 254.

${ }^{18}$ Beberapa teolog seperti A.T Lincoln dan Von Rad menyetujui bahwa materi "tempat perhentian" dalam Ibrani 4: 4 yang mengutip dari Kej. 2:2 memiliki nuansa Eskatologis. Kejadian 2:2 merupakan penyempurnaan dari keseluruhan pekerjaan Allah dalam penciptaan dan tujuan Allah dalam penciptaan. Apakah yang menjadi tujuan Allah bagi gereja? Tuhan menebus jemaat dan memberi kemuliaan kepada mereka di sorga.
} 
perjanjian baru dari Allah kepada gereja. Beberapa komunitas dalam kondisi bahaya ketika mereka menolak kabar baik tersebut (Ibr. 4:1-2). Dalam konteks ini penekanan penulis adalah pada kehidupan yang beriman penuh kepada Allah yang telah melepaskan dari "pengembaraan" hidup untuk memeluk dan mengimani kabar baik yang telah diberitakan oleh Allah. Jadi akhirnya, tempat perhentian dapat dicapai melalui iman (Ibr. 4:3) dan akan disempurnakan pada akhir zaman.

\section{KESIMPULAN}

Dasar dari peneleaahan peningkatan pikiran adalah progressive revelation. Berdasarkan struktur kitab yang telah disusun maka hukum struktur yang dipakai oleh penulis adalah peningkatan pikiran. Ibrani 3-4 berisi tentang perbandingan antara Perjanjian Lama yang diwakili oleh Musa dan Perjanjian Baru yang diwakili oleh Yesus sang Imam besar. Salah satu topik yang dibahas dalam perbandingan tersebut adalah mengenai tempat perhentian.

Pola yang sama dikembangkan penulis dalam Ibrani 8-9. Ibrani 8 dan 9 berisi perbandingan pelayanan Perjanjian Lama dan pelayanan Kristus pada Perjanjian Baru. Salah satu topik yang dibahas pada perbandingan tersebut adalah perbandingan antara tempat kediaman di bumi dan tempat kediaman di Sorga (Ibrani 9:1-11).

Ibrani 9:1-11 merupakan representasi pola pelayanan selama mereka berada di tanah Kanaan. Ibrani 9:11-2 merupakan representasi keberadaan sorga. Bahkan dalam Ibrani 9:23-24 disebutkan secara tegas bahwa konteks nas ini adalah sorga yang dibangun oleh Allah sendiri. Secara sederhana penulis menggambarkan peningkatan pikiran penulis kitab sebagai berikut:

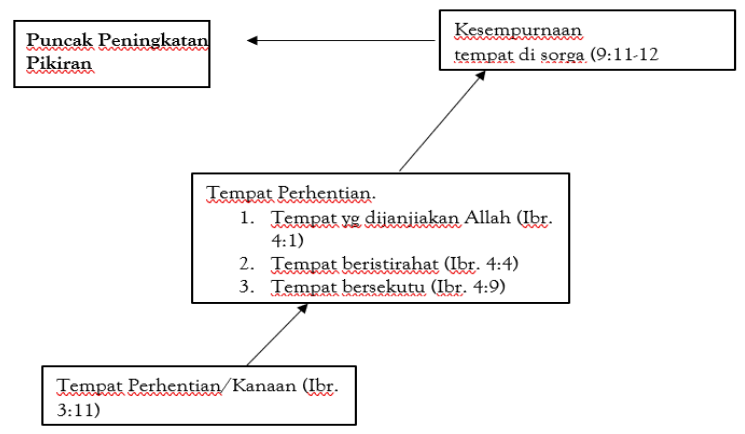

Baik nas-nas Perjanjian Lama maupun Perjanjian Baru menyinggung pentingnya iman dan kesetiaan kepada Allah merupakan sarana menuju tempat perhentian yang telah disediakan Allah. Kejadian 2:2 menjelaaskan bahwa hari perhentian merupakan waktu Allah menyempurnakan dan memberkati ciptaanNya. Ulangan 31:7 dan Yosua 1:3 menjelaskan bahwa tempat perhentian akan dicapai melalui iman kepada TUHAN. Mazmur 95:11 menjelaskan bahwa mereka yang tidak beriman tidak dapat masuk pada tempat perhentian yang menawarkan kedamaian yang abadi.

Jadi surat Ibrani 4:1-10 menjelaskan bahwa iman kepada Tuhan Yesus adalah sarana menuju tempat perhentian yang abadi. Orang beriman akan memasuki tempat peristirahatan yang penuh dengan kedamaian (Ibr. 4:3-7 dan Mzm. 95:11). Kaum kudus akan disempurnakan dan diberkati Allah pada masa perhentian kelak (Ibr. 4:2 dan Kej. 2:2). Hanya mereka yang beriman kepada Tuhan Yesus yang akan masuk ke dalam tempat perhentian tersebut (Ibr. 4:8 dan Ul. 31:7; Yos. 1:3).

\section{KEPUSTAKAAN}

Adiatma, Daniel L. "Teknik Tafsir Pemakaian Perjanjian Lama Dalam Perjanjian Baru.” Academia.edu (2019).

Beale, Gregory K. Penggunaan Perjanjian Lama Oleh Perjanjian Baru. Malang: SAAT, 2015.

Brown, Collin. New Testament Theology. III. Grand Rapids: Regency Library, 1993.

Eep, Eldon Jay., and D. Fee, Gordon. Studies In The Theory and Method of New Testament Textual Critisism. Grand Rapids: William B. Eerdmans Publishing Company, 2000.

Fowler, James A. A Commentary on the Epistle to The Hebrew. Fallbrook: C.I.Y Publishing, 2006.

Friberg, Barbara, Timothy Friberg, and Neva F. Miller. Analytical Lexicon of The New Testament. Grand Rapids: Baker Books, 2000.

Gingrich, Wilbur F. Shorter Lexicon of the Greek New Testament. Edited by Frederick W 
Danker. 2nd ed. Chicago: The University of Chicago Press, 2007.

Guthrie, George H. "Hebrew." In Commentary On The New Testament Using Old Testament, edited by Gregory K. Beale and D A. Carson. Grand Rapids: Baker Academic, 2007.

Hanson, A.T. "Hebrew." In It Is Writen Scripture Writing Scripture, edited by D A. Carson. Cambridge: Cambridge University Press, 1988.

Holladay, William L. A Concise Hebrew and Aramaic Lexicon of the Old Testament. Leiden: Koninklijke Brill NV, 2000.

Stedman, Ray C. "Hebrews." In The New Testamnet Commentary Series, edited by Grant R Osborne. Downers Grove: InterVarsity, 1992.

Wallace, Daniel B. Greek Grammar Beyond the Basis: An Exegetical Syntax of the New Testament. Grand Rapids: Zondervan Publishing House, 1996. 